\title{
THE ROLE OF JUSTICE COLLABORATOR IN UNCOVERING CRIMINAL CASES IN INDONESIA
}

\author{
Hambali Thalib ${ }^{1}$, Sufirman Rahman ${ }^{2}$, Abdul Haris Semendawai ${ }^{\mathbf{3}, 4}$ \\ ${ }^{1,2}$ Faculty of Law, Universitas Muslim Indonesia \\ ${ }^{3}$ Doctoral Student, Department of Criminal Law, Moslem University of Indonesia \\ ${ }^{4}$ Chairman Of Witness And Victim Protection Agency, Indonesia \\ Corresponding Author: adhie.djanggih@gmail.com
}

\begin{abstract}
The purpose of this research is to study the role of justice collaborator in uncovering who is the mastermind behind a major crime in the act of criminal law, and also not only end on a minor defendant (field defendant). The empirical law research methods is conducted on the Commission Eradication Commission (KPK) and the Witness and Victim Protection Agency (LPSK). The results shows that the role of justice collaborator facilitates the verification in the criminal judicial process in order to totally reveal the well-organized transnational crime. In this context, corruption in Indonesia is committed collectively, the existence of regulations on justice collaborator is a legal instrument that is expected to strengthen the collection of Form of Evidence dan Real Evidence at the trial.
\end{abstract}

Keywords: Role, Justice Collaborator, Criminal case, Indonesia

\section{Introduction}

The success (or failure) of a criminal case is heavily influenced by witness testimony that were presented at the trial. ${ }^{1}$ As stipulated in Law Number 13 of 2006 on Witness and Victim Protection, in General ExplanationI, adduces that the success of the criminal judicial proceedingstrongly relies on the means of proof that has been disclosed or discovered. At hearing, especially with regard to the witness, many cases were unrevealed due to the absence of witnesswho is be able to supportour law enforcer tasks. ${ }^{2}$

1 Weny, A.D, Implementasi Undang-Undang perlindungan Saksi dan Korban Di Kota Gorontalo, Jurnal Mimbar Hukum, Vol.21, No.2, Juni 2009, p.298

2 Meigi B. Barapa, Perlindungan Hukum Terhadap Saksi dan pelapor Tindak Pidana Gratifikasi, Jurnal Lex Et Societatis, Vol.1., No.2, 2013, p.50 
The enactment of Law Number 13 of 2006 on Witness and Victim Protection has four purposesin its formulation as follow: firstly, to fill the regulation gap of the witness, the (crimes) victim, the complainant and the justice collaborator which in Criminal Procedure Code (KUHAP) (equality before the law); secondly, to stop various illegal practices which hinder a witness or complainant to testify honestlyor discontinue reports through violent ways, legal entanglement, enticements and any other method in the form of physical or psychological oppression;Thirdly, to encourage the creation of an conducive atmosphere in order to drive people participating in the prevention and eradication of various criminal act, particularly a felony (serious crime); andfinally, fulfill the rights of crime victims by helpingthem resolve any issues that emerge from the committed crimes. ${ }^{3}$ The Law Number 13 of 2006 and the Criminal Procedure Code are the reason that in dealing with something new, according to SatjiptoRahardjo, would requires ProgressiveLaw where law is for human being. ${ }^{4}$

In performing the assistance of witness and victim protection, it must be cooperated and executed with the competent agencies (law enforcer) as stipulated in provision Article 36 Law Number 13 of 2006 as amended to Law Number 31 of 2014 on Protection of Witness and Victim in verse (2); "In performing the protection and assistance as referred to in paragraph (1), the relevant agencies in accordance with their authority obligatory to implement the LPSK's decision in accordance with the provisions stipulated in this law." 5

In Law on Protection of Witness and Victim, rights of the cooperated witness (justice collaborator) is regulated to met a sense of security as a standard service of authorized agencies in implementing various act of legal protection that has been pledged before, either by request itself or by another person or institution,

3 Abdul Haris Semendawai Kedudukan dan Kontribusi Whistle Blower dan Justice Collaborator dalam Paradigma Penegakkan Hukum Tindak Pidana Korupsi dan Pencucian Uang, Makalah pada seminar \& diskusi publik Jakarta, 26 Juli 2013

4 Syamsul Fatoni, Urgensi Perlindungan Saksi dan Korban Dalam Mengungkap Kasus Kekerasan Dalam Rumah Tangga, Jurnal Mimbar Hukum, Vol.26, No.3, Okt. 2014, p.447

5 Abdul Haris Semendawai, Op.Cit 
in this case including the infrastructure, facilities, and institutions that will provide legal protection, and justice collaborator interests.

The cooperation aspects ofvarious parties, mainlyfrom law enforcer and other stakeholders isextremely important and crucial element in implementation of the protection process (procedure) in Indonesia. This fact is shown by the overwhelming attention by the Act of Witness and Victims Protection in organizing the importance of collaboration from parties particularly theauthorized agency that providing such protection.

The emerge of joint regulation by the Minister of Law and Human Rights of the Indonesian Republic, TheIndonesian Attorney General, the Indonesian National Police, the Corruption Eradication Commission (KPK), and Witness and Protection Agency (LPSK), Number 4 of 2011 on the Protection of the Informant, Whistle Blower,and Justice Collaborator,and the Supreme Court CircularLetter Number 4 of 2011 on the Treatment to Whistleblowerand Justice Collaborator in certain criminal law case ${ }^{6}$, became the strengthening part of rule of law in preserving the whistleblower andjustice collaborator.

In principle, to determine the status of a person to be a whistleblower and/or justice collaborator is an institution or an agency that has acquaired an Acceptance Reporting mechanism which are credible, simple and professional, the certainty of the follow-up report, the clear information to the witness on the report progress and also the ability to protect the witness. ${ }^{7}$

Therefore, the prosecution from year to year became important to protect the witnesses and victims including the protection of the justice collaborator in order to reveal the sophisticated and well-organizedcriminal cases. It was realized

6 In Law Number 31 of 2014 on the Amendment of Law Number 13 of 2006 on Witness and Victim Protection, including with certain criminal act, among others. human rights violations criminal act, corruption criminal act, money laundering criminal act, terrorism criminal act, human trafficking criminal act, narcotic/ psychotropic (drugs) criminal act, child sexual abuse criminal act, and other criminal acts that resulted in the position of the Witness and Victim are faced with a situation that is very endanger his life. 
that theircircumstances is very vulnerable to any threats/intimidation that can harm their body and soul as well as its future viability or even potentially criminalized. In reality, there are so many justice collaborator are also judged the same sentencewith the other suspects. In other words, their contribution to expose the crime depthly, widely, and fastly, have not been taken into accounted at all by Indonesian law enforcer,eventhough there is actually the act whichregulates it. ${ }^{8}$

Even though it is already set in the legislation as well as a number of internal rules and joint regulations, however the indictment status and rightsof Justice Collaborator (JC) are still often neglected, JC has not been fully utilized. It can be seen from the judicial proceedings, i.e; 1. He informs/testifies, he also getting involved, then he can be charged as a field actor/perpetrator; 2. Do not admit that the disclosure of a case due to the contribution of JC; 3. Law enforcement officer still consider/assume, withoutthe status of JC, a suspect can also testify as a crown witness; 4 . Status of JC is misused to protect some particular interests or to gain certain advantages;5. Acquaire the stigma, while JC should be an opportunity for the suspect/defendant to makeredemption. Their courage to unvealcrime and bear witness the truth can be a way to gainforgiveness from The Almighty God; 6. There are technical problems related to the authorized institutions that determine the status of JC and the need for a certitude mechanism to get and provide JC ;7. The punishment for those who granted as JC is also has no definitive standards/procedure, as if there is no legal assurance.

\section{Research Methods}

This study applies socio-juridical law research, which review the legal issues with social approach towards justice collaborator's role in exposing crimes in Indonesia.

\section{Result and Discussion}

Nurhikmah Saleh, Skripsi "Kajian Yuridis Terhadap Justice Collaborator dalam Mengungkap Tindak Pidana Korupsi, Fakultas Hukum, Universitas Hasanuddin, Makassar, 2013. 
The Justice Collaborator is a witness involved in the crimes investigated. ${ }^{9}$ The utilization of justice collaborator in uncovering criminal cases is highly restricted to certain crimes which is felony (serious act of crime) as stipulated in Supreme Court Circular Letter (SEMA) Number 4 of 2011 such as corruption, terrorism, narcotic act of crime, money laundering, trafficking, and such wellorganized crimes, has caused a big problem and threat to the stability and security of societies so that overthrow the institutions and values of the democracy, ethics and justice and endanger the sustainable development and the law supremacy.

The use of those justice collaborator status, it was truly has two interests; 1) The interests of law enforcement officers in helping to solve a serious crime; 2) The interests of the suspect/defendant in order to gain lighter judgment as well as other rights. When a person is arrested by the Corruption Eradication Commission (KPK), then do not ever dream to escape the law. Even if they hope to receive commutation, one of the ways is becominga the cooperatedwitness (justice collaborator).

AgusRahardjo, chairman of KPK, said "many of the corruption actor were dealt by KPK proposed justice collaborator to get commutation, but not all of them could be met.KPK has been criticized widely by some parties as its stingy decision to givethe status of a justice collaborator. This is due to the strict requirements to be determined as a justice collaborator."10

On another occasion, AgusRahardjo said "To be a justice collaborator in $\mathrm{KPK}$,a witness of perpetrator must qualify some requirements,such as admit his crime, he was not the mastermind (main actor), returning the assets or the yield of corruption to the country, willingness to reveal the another perpetrator or cases, and

9 Muhammad F.A., dkk, The Reform Of Corrution In Indonesian: The Prismatic LawIn The Recent Context, Jurnal Mimbar Hukum, Vol. 25, No.1, Feb.2013, p.189 
willingness to give testimony at the hearing and also consistent with the Interrogation \& Investigation Report (BAP)." 11

Based on the data from KPK, during 2015-2016,There was 48 suspects of corruption investigated by this commission had submitted justice collaborator appeal. However, not all of the submission were fulfilled. Of the 48 petition, currently only 11 people who received as a justice collaborator. The rest of 26 application was rejected because it was not qualify and 11 petition was still processing by KPK and waiting for the consistency of their testimony at the trial.

According from the records of antikorupsi.org ${ }^{12}$, a number of corruption cases that was handled by KPK revealed because of justice collaborator's contribution. For instance, Hambalang and Athletes Pensions project (bribing parliamentarians to get infrastructure projects), social aid fund bribery (Bansos) in the province of north Sumatra, and bribingthe judge of the State Administrative Court in Medan. The actor of corruption that ever entitles the status of justice collaborator by KPK, among others AgusCondro, Wahid Muharram, Kosasih Abbas, Abdul Khoir, RineldaBandaso, YagariBhastara Guntur, and M. Nazaruddin.

The form of protection granted to justice collaborator encompasses physical and legal protection. Physical protection including surveillance and escort, the replacement (compensation)of cost of living, and transfer to the safe house, which can be performed by LPSK or Penitentiary in accordance with its duties and functions. While legal protection and rewards granted to the cooperated witness of perpetrator including receivingthe information with regard to the case,the commutation or (leniency of prosecution), and the recommendation to get remission and parole.

11 The explanation of KPK's Chairman was adduced in Coordination Meeting (Rakor) with law enforcement officer and stakeholders to fulfill the rights of witness and victim in Denpasar, June the $1^{\text {st }}, 2016$, held by Witness and Victim Protection Agency (LPSK)

12 ICW, "4 Pelaku Korupsi Minta jadi Justice Collaborator kepada KPK”, dikunjungi tanggal 10 Januari 2017, http://www.antikorupsi.org/id/content/48-pelaku-korupsi-minta-jadi-justicecollaborator-kepada-kpk. 
KPK protection efforts upon justice collaborator is also still undergoing several obstacles. Obstacles encountered when the witness of perpetrator who is protected by KPK is also reported to the other law enforceragencies for example in the case of forgery, perjury and defamation. In fact, some of them suffered threats or disruption to their safety of their families, such as physical intimidation, destruction of homes or cars. ${ }^{13}$

Another thing that impeded according to AgusRaharjo is the contradictionof view/ opinion with the judges who adjudicated certain corruption cases that reject the enactment of an accused became justice collaborator, eventhough it was already proposed and approved by KPK. ${ }^{14}$

To overcome these issues, KPK has made a number ofprecaution measures such as cooperate with the police officer to precede the justice collaborator, requested a postponement (report) in advance until his corruption cases that still proceeding at trial decreed by the Criminal Corruption Court. In addition to the corruption court, in practice, the use of justice collaborator in Indonesia is relatively new that performed for narcotics and money laundring cases.

KPK's data in 2016 on suspect and defendant who proposed as a justice collaborator are demonstrated in the following table 1;

\section{Table 1}

Proposal for Justice Collaborator Status in 2016

\begin{tabular}{|c|c|c|c|c|c|}
\hline \multirow{2}{*}{ Proposal } & \multicolumn{5}{|c|}{ Proposal Status } \\
\cline { 2 - 6 } & Approved & Rejected & Pending & Cancelled & Not Qualified \\
\hline $\begin{array}{c}57 \\
\text { petitioner }\end{array}$ & $\begin{array}{c}12 \\
\text { petitioner }\end{array}$ & $\begin{array}{c}34 \\
\text { petitioner }\end{array}$ & $\begin{array}{c}7 \\
\text { petitioner }\end{array}$ & $\begin{array}{c}1 \\
\text { petitioner }\end{array}$ & $\begin{array}{c}3 \\
\text { petitioner }\end{array}$ \\
\hline
\end{tabular}

Source: Primary data after processing, 2017 
Based on the table, it can be concluded thatit was not easy to become a justice collaborator. Only 12 of 50 petitioner are accepted,it means that only about 24 percent proposals were granted. Of the 12 justice collaborator, there are some wellknown names as SukotjoBambangand GatotPujoNugroho. The names of the justice collaborator as follows;

(1) EV, Bribery case at State Administrative Court in Medan, approved by the decree number: KEP-1205/01-55/12/2015, date:Desember the $8^{\text {th }}, 2015$.

(2) DP, Procurement of Health Equipment case in South TangerangRegency. TA.2012, approved by the decree number:KEP-906/01-55/09/2015, date: September the $29^{\text {th }}, 2015$;

(3) TIP, Bribery case at State Administrative Court in Medan, approved by the decree number: KEP-892/01-55/09/2015, September the $23^{\text {th }}, 2015$;

(4) SF, LKPJ case on Regent of Musi, BanyuasinTA.2015, approved by the decree number: KEP-816/01-55/09/2015 September the $21^{\text {th }}, 2015$;

(5) F, LKPJ case on Regent of Musi, Banyuasin TA.2015 approved by the decree number: KEP-815/01-55/09/2015, September the $21^{\text {th }}, 2015$;

(6) GPN, Bribery case at State Administrative Court in Medan, approved based on the decree number: KEP-1206/01-55/12/2015, Desember the $8^{\text {th }}, 2015$;

(7) AM, LKPJ case on Regent of Musi, Banyuasin, TA.2015, approved by the decree number: KEP-1104/01-55/07/2015, November the $11^{\text {th }}, 2015$;

(8) BK, LKPJ case on Regent of Musi, Banyuasin,TA.2015, approved based on the decree number: KEP-1105/01-55/07/2015, November the $11^{\text {th }}, 2015$;

(9) SSB, SIM-Koorlantas Police Simulator cases, approved by the decree number: KEP-918/01-55/08/2016, August the 22 ${ }^{\text {th }}, 2016$;

(10) MYBG, Bribery case at State Administrative Court, Medan, approved by the decree number: KEP-649/01-55/07/2015, July the $29^{\text {th }}, 2015$;

(11) RBT, Governor of North Sumatra case, approved by the decreed number: KEP/01-55/12/2015, Desember the $12^{\text {th }}, 2015$; 
(12) $\mathbf{R}$, Land Swap cases in Local Government,Tegal, approved by the decree number: KEP-357.01-55.03.2016. March the $21^{\text {th }}, 2016$.

(Noted: the full name of justice collaborator, no researcher, intentionally is not published due to the judicial proceedings)

The importance of the justice collaborator is shown by the role that they played on elucidation abovementioned. As an further explanation, the case of SSB and $\mathrm{R}$ as justice collaborator will be elaborated below.

\section{a. SSB}

SSB is the cooperated witness of perpetrator (justice Collaborator) in the act of corruption case in procurement of 2 wheel and 4 wheel driving simulators atKorlantas Police TA. 2011, which was handled by KPK.The case was decreed by the Panel of Judges of Criminal Corruption Court, Central Jakartaand this judgment of conviction has been affirmed(res judicata). The enactment of the Petitioner as a cooperative Witness of Perpetrator based on the decree of the Corruption Eradication Commission Leader of Indonesia Number: KEP-918/0155/8/2016 On Stipulation of the Cooperated Witness of Perpetrator in act of corruption, on behalf of SukotjoSastronegoroBambang, August the $22^{\text {th }}, 2016$.

SSB is considered to contribute in uncovering the driving simulators case in Korlantas Police Headquarters with an assistanceto KPK in providingan testimony in exposing the involved actors/main suspects such as DjokoSusilo, Budi Susanto and DidikPurnomo, from the first step of the investigation until at the trial, which has been judgedcompletely by Criminal Corruption Court decree. As acooperated Witness of Perpetrator, his verdict (sentence) was lighter rather than the other actors who has a greater role.

The existence of a Protected One as a witness is crucial according to KPK, regarding that the Protected One has helped the officer to uncover and testify for 3 other perpetrators who was considered as the main actors. The decision of the Panel of Judges of Criminal Corruption Court, Central Jakartatowards the main actors as follows: 
1) DjokoSusilo, sentenced 10 (ten) years in prison, fined IDR 500.000.000, (five hundred million rupiahs). On cessation level, sentenceincreased into 18 (eighteen) years imprisonement, finedIDR $1 \mathrm{M}$ (one billion rupiahs), Reimbursement in the amount of IDR $32 \mathrm{M}$ (thirty two billion rupiahs) subsidiary 5 (five) yearsimprisonement;

2) Budi Susanto, sentenced 8 (eight) years in prison, fined IDR 500.000.000,(five hundred million rupiahs) subsidiary 6 (six) month imprisonement. Reimbursement in the amount of IDR 17,13 (seventeen point thirteen billion rupiahs) subsidiary 2 (two) years imprisonement. On appeal level affirm the decree of first-class district court.

3) DidikPurnomo, sentenced 5 (five) years in prison, fined IDR 250.000.000,(Two hundred and five million rupiahs) subsidiary 3 (three) month imprisonement.

As a justice collaborator, his verdict was lighter than the other actors who have a greater role. SSB was sentenced by The Panel of Judges of Criminal Corruption Court, Central Jakarta with 4 (four) years imprisonement, fined of IDR 200,000,000,- (two hundred million rupiahs) subsidiary 3 (three) months, pay compensation in the amount of IDR $3.933 \mathrm{M}$ (three point nine hundred and thirty three billion rupiahs) subsidiary 1 (one) year.

With regard to readiness to pay the fine and the restitution, SSB basically willing to pay (with a written statement), however, SSB could not afforded it due to the inability of economic. All of his company assets had been usurped by Mr. Budi Susanto. Hence, SSB still endeavouredand alsoasked the KPK prosecutors related to his assets that was confiscated from $\mathrm{Mr}$. Budi Susanto(SSB's company assetswas included in it). But, if his assets are not included in Budi Susanto's indictment files, then the SSB's assets is still possible to be withdrawn, so that it can be used to pay the intended fine and restitution. Until now, KPK prosecutors has beensearching for Budi Susanto's case files. 
Currently, SSB is undergoing an imprisonment atFirst-Class Jail in Bandung (Kebonwaru). This is undertaken to avoid SSB occupy the same jail/prison with other perpetrators, while they in prison at Sukamiskinjail, Bandung. SSB was the last suspect in the criminal corruption case of driving simulator 2 and 4 wheel procurement in Korlantas Police Department.

Based on the description above, SSB's rights as a justice collaborator have been fulfilled as following; 1 . His trial was held lastly compared to other corruption actors; 2. The inflicted sentenced upon him was the lightest one compared to other corruption actors; 3. The detention and the penientiaryof SSB wasseparated by other corruption actors who was associated with him.

\section{b. $\mathbf{R}$}

$\mathrm{R}$ as a justice collaborator in land swap (ruislag) corruption casebetween the (owned land) local government of Tegal and 2 (two) businessman, namely $\mathrm{R}$ and SyaefulJamil, hereinafter this case was handled by KPK. Status of $\mathrm{R}$ as a justice collaborator decided by KPK based on decree Number: KEP-357.0155.03.2016. March the $21^{\text {th }}, 2016$. The chronologyof this case can be watched as following:

In the beginning, $\mathrm{R}$ bought a land which is adjacent area to the land owned by the local government of Tegal, and there were two crooked land that should not be commercialized. In this regard, $\mathrm{R}$ applied for a permit to buy two parts of the crooked land, but the requested permit was rejected by the Head of State Governance of Tegal (Hartoto). Furthermore, this land was built and became Vocational Training Center.

After theoccurence, precisely in 2012, Hartoto contacted $\mathrm{R}$ to offer a cooperation between the $\mathrm{R}$ and the local government of Tegal. Hartotopropose for land ruislagcooperation (owned by TegalGovernment City) to be used as a landfill (TPA). At the moment, $\mathrm{R}$ hasnot yet the land that couldbe ruislag, so Hartoko offered to $\mathrm{R}$ to purchasethe land owned by mayoressof Tegalwhich 
located in Bokongsemar area. According to Hartoto, thatsite was suitable for the needand utility of the landfill.

Since May, 2014, theruislag project was started. At that time, R firslysummoned an appraiser to estimate the price of the land that he wanted to buy. The resulted calculation from the appraiserwas IDR 175,000,- (one hundred and seventy five thousand rupiahs) to IDR 210.000,- (two hundred and ten thousand rupiah) per meters. Petitioner purchased 7 (seven) hectares. Besides, there are other parts of the land, the appraiser estimated the price of IDR 220.000,- (two hundred and twenty thousand rupiahs) to IDR 245.000,(two hundred and forty-five thousand rupiah) per meters, and Petitioner bought it 3 (three) hectares.

After the purchasing of the land, then $\mathrm{R}$ handled for all of the landfill technical and construction requirements inBokongsemar. Applicant prepared the permit letters, including the Environment and Social Impact Assesment (AMDAL). Once all the requirements wascompleted, $\mathrm{R}$ began to build that land by leveling the ground at first and contrived the boundaries. At that moment, there was an verificationby State Development Audit Agency(BPKP), which stated that the country suffered losses of IDR $11.5 \mathrm{M}$ (eleven point five billion rupiahs) because the price of land was below the market prices. According to the BPKP's audit, its market price was IDR. 950.000,- (nine hundred and fifty thousand rupiah) per meter.

In ruislagproject proceedings, $\mathrm{R}$ was frequently asked for some money by the officials government of Tegal, such as the mayor, The Secretary, Hartoto, National Land Agency (BPN) employees, and the realtor (They were Hartoto's man either). $\mathrm{R}$ conveyed that the total amount of money given to these officials was IDR $1 \mathrm{M}$ (one billion rupiah).

The results of the investigation by BPKPwasthen followed up toKPK for the enforcement of criminal law. KPK enacted the Mayor of Tegal, Ikmal Jaya and one of the businessmen called SyaefulJamil as suspects. On the other hand, 
$\mathrm{R}$ then reimbursedIDR $11 \mathrm{M}$ (eleven billion) through KPK investigators and were willing to cooperate with. Hereinafter, $\mathrm{R}$ became a witness to the thosetwo suspects.

In August the 12 $2^{\text {th, }}$ 2015, Semarang Criminal Corruption Court had sentenced;

1) Ikmal Jaya was found guilty with an imprisonement sentence of 5 (five) years, fined IDR 300.000.000,- (three hundred million), and reimbursement of IDR 350,000,000,- (three hundred and fifty million rupiahs).

2) SyaefulJamil was found guilty with animprisonementsentence of 5 (five) years, fined IDR $\mathrm{Rp} 300.000 .000$,- $^{-}$(three hundred million), and reimbursement of IDR 20,32 M,- (twenty point and thirty two billion rupiahs).

For the judgment, the two defendants appealed and it was decided the following:

1) Ikmal Jaya was found guilty with an imprisonementsentence of 8 (eight) years, fined IDR Rp 300.000.000,- (three hundred million), and reimbursement of IDR 350,000,000,- (three hundred and fifty million rupiahs).

2) SyaefulJamil was found guilty with an imprisonementsentence of 7 (seven) years, fined IDR Rp 300.000.000,- (three hundred million), and reimbursement of IDR 350,000,000,- (three hundred and fifty million rupiahs).

Furthermore, they submitted a deed of petition for cassation to Indonesian Supreme Court (MA), however MA rejected their petition.

Then, on October the $15^{\text {th }}, 2015$, KPK decreed the petitioner as a suspect of this case and detained as from November the $24^{\text {th }}, 2015$. $\mathrm{R}$ was charged of breaking the Article 2 verse (1) or Article 3joArticle 18 of Law Number 31 of 1999 as amended toLaw Number 20 of 2001 on Corruption Eradication joArticle 55 verse (1) to 1 KUHP.

On March the $21^{\text {th }}, 2016, \mathrm{R}$ was stipulatedas a justice collaborator by KPKby the Decision of KPK's Leaders Number: KEP-357/01-55/03/2016 on 
Stipulation of the Cooperated Witness of Perpetrator (Justice Collaborator) in Criminal Corruption on behalf The Defendant,Rudyanto.

On April the $19^{\text {th }}, 2016$, Semarang Corruption Court Decree: Number 16/Pidsus-TPK/2016/PN SMG April 19 ${ }^{\text {th }}$, 2016, has adjudicated its judgementto Rudyantofor breaking the Article 3 of Law Number 20 of 2001 on Corruption Eradication. The verdict was:

1) Imprisonment for 2 (two) years, reduced by the amount of time he's already been detained.

2) Fined of IDR 100.000.000,- (one hundred million rupiahs).

3) Additional punishment which is reimbursing to the state in the amount of IDR 11.725835 billion,- (eleven billion seven hundred and twenty five million eight hundred and thirty five thousand rupiahs), which is calculated by the amount of money that was deposited to Rudyanto, while the excess payment of IDR $342000000,-$ (three hundred and forty two million) was refunded to Rudyanto.

Currently, $\mathrm{R}$ is serving his sentence at the First Class Correctional Facility of Kedungpane, Semarang. $\mathrm{R}$ through his attorney has requested his rights as a justice collaborator. $\mathrm{R}$ also has submitted for assimilation and parole, but up to now,there has been no any information about the follow-up.

From the description above, a number of R's rights as a justice collaborator have been fulfilled as follows: 1. His trial was held lastly compared to other actors; 2. The sentenced upon him was the lightest one compared to other actors; 3 . The detention and the jail of SSB wasseparated by other actors who was associated with him.

Those two abovementioned examples of justice collaborators, it can be adduced the following: 1. It is not easy (simple) to becomea justice collaborators, they had to passed long and tight screening. Justice collaborator status is often granted when the legal proceedings have been finished. In fact, some of them afterthe candidate of justice collaborator had testified to other defendants in the 
same case or after other defendants have been sentenced; 2. Status of justice collaborator is granted after KPK convinces that the concerned onehas contribution and significant role in exposing the evil and they must exhibittheir seriousness in exposing the crimes and also demonstratea good conviction and truly willing to cooperate with law enforcement officers, not merely pursuit such special protection, treatment and award; 3Those who granted a status as justice collaborator entitles to receive the rights which is stipulated in the legislation; and 4. The fulfillment of these rights have already been met, but there are things that still need to be strived hardly by the justice collaborator.

\section{Conclusion}

The role of justice collaborators aims to assistthe verification and prosecution proceeding at hearing and they are also be capable of revealingcertain criminal cases completely, particularly related to the well-organized transnational crimes. In this context, corruption in Indonesia is never perpertrated individually, but collectively, the existence of provisions that regulates in regard with justice collaborator is a legal instrument, expected to strengthen the collection of form of evidence and real evidence at trial.

\section{Recommendation}

Those who granted a status as justice collaborator is expected to receive their rights that stipulated in the legislation whichregulates the justice collaborator. To justice collaborators, they must exhibittheir seriousness in exposing the crimesand also demonstratea good conviction and truly willing to cooperate with law enforcement officers, not merely pursuit such special protection, treatment and award.

\section{Reference}

Weny, A.D, Implementasi Undang-Undang perlindungan Saksi dan Korban Di Kota Gorontalo, Jurnal Mimbar Hukum, Vol.21, No.2, Juni 2009, p.298 
Abdul Haris Semendawai Kedudukan dan Kontribusi Whistle Blower dan Justice Collaborator dalam Paradigma Penegakkan Hukum Tindak Pidana Korupsi dan Pencucian Uang, Makalahpadaseminar \& diskusi publik Jakarta, 26 Juli 2013.

Meigi B. Barapa, Perlindungan Hukum Terhadap Saksi dan pelapor Tindak Pidana Gratifikasi, Jurnal Lex Et Societatis, Vol.1., No.2, 2013

Nurhikmah Saleh, Skripsi "Kajian Yuridis Terhadap Justice Collaborator dalam Mengungkap Tindak Pidana Korupsi, Fakultas Hukum, Universitas Hasanuddin, Makassar, 2013

Muhammad F.A., dkk, The Reform Of Corruption In Indonesian: The Prismatic LawIn The Recent Context, Jurnal Mimbar Hukum, Vol. 25, No.1, Feb.2013.

Syamsul Fatoni, Urgensi Perlindungan Saksi dan Korban Dalam Mengungkap Kasus Kekerasan Dalam Rumah Tangga, Jurnal Mimbar Hukum, Vol.26, No.3, Okt. 2014.

ICW, "4 Pelaku Korupsi Minta jadi Justice Collaborator kepada KPK”, dikunjungi tanggal 10 Januari 2017, http://www.antikorupsi.org/id/content/48-pelakukorupsi-minta-jadi-justice-collaborator-kepada-kpk.

\section{Law Documents}

Law Number8 of 1981 on Criminal Law

Law Number 39 of 1999 on Human Rights (HAM)

Law Number 13 of 2006 on Protection of Witness and Victim

Law Number 31 of 2014 on Amendment Law Number 13 of 2006 on Protection of Witness and Victim 